\title{
Annual Technology Baseline: The 2020 Transportation Update
}

Laura Vimmerstedt, Paige Jadun, Chris Kinchin, and Matteo Muratori (NREL)

Amgad Elgowainy, Dave Gohlke, Ehsan Islam, and Aymeric Rousseau (Argonne National Laboratory) 


\section{Agenda}

- Why the ATB?

- ATB Project Overview

- Website Demonstration

- Questions and Comments 


\section{Why the ATB?}

- The rapid pace of technology development results in reports of technology progress becoming rapidly outdated, making it difficult for researchers to find current, credible, and consistent information in one place.

Annual Technology Baseline

ATB Electricity

The NREL Annual

analysis. And the A

To inform electric

input assumptions
ATB Transportation v

Contact Us

About

Technologies

Data

Data

\section{atb.nrel.gov}

- By enabling understanding of technology cost and performance across energy sectors, the ATB informs transportation sector analysis nationwide. 
ATB Project Overview 


\section{What are the content and purposes of the ATB?}

\section{The ATB is a ...}

- Website and summary data set of cost and performance estimates for selected vehicles and fuels

- Link to publicly available resources

- A set of scenarios that highlight potential technological improvements

- Platform for interactive exploration, selection, and download of specific data.

\section{The ATB is not a ...}

- Primary analysis

- Model

- Set of all-encompassing future scenarios.

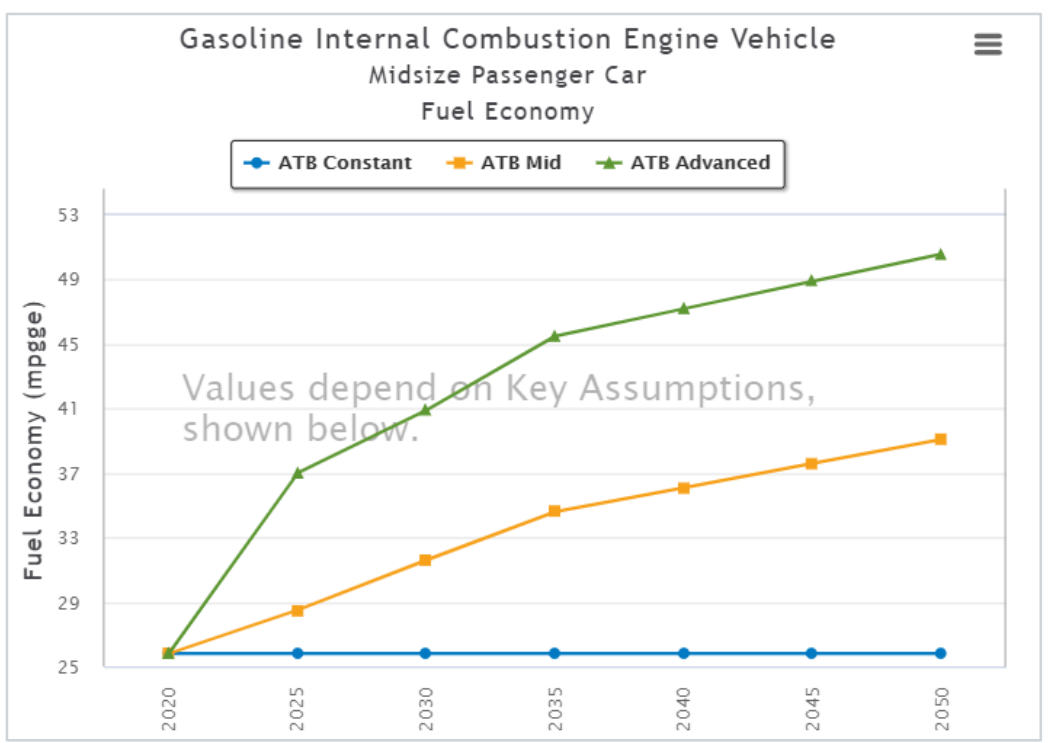




\section{The ATB highlights key data.}

"Inputs"

Vehicle

Component

Costs

Fuel Cell, Battery

Costs, etc.

Fuel/Blendstock Pathways

Feedstock Costs, Operating Costs, etc.
Outputs

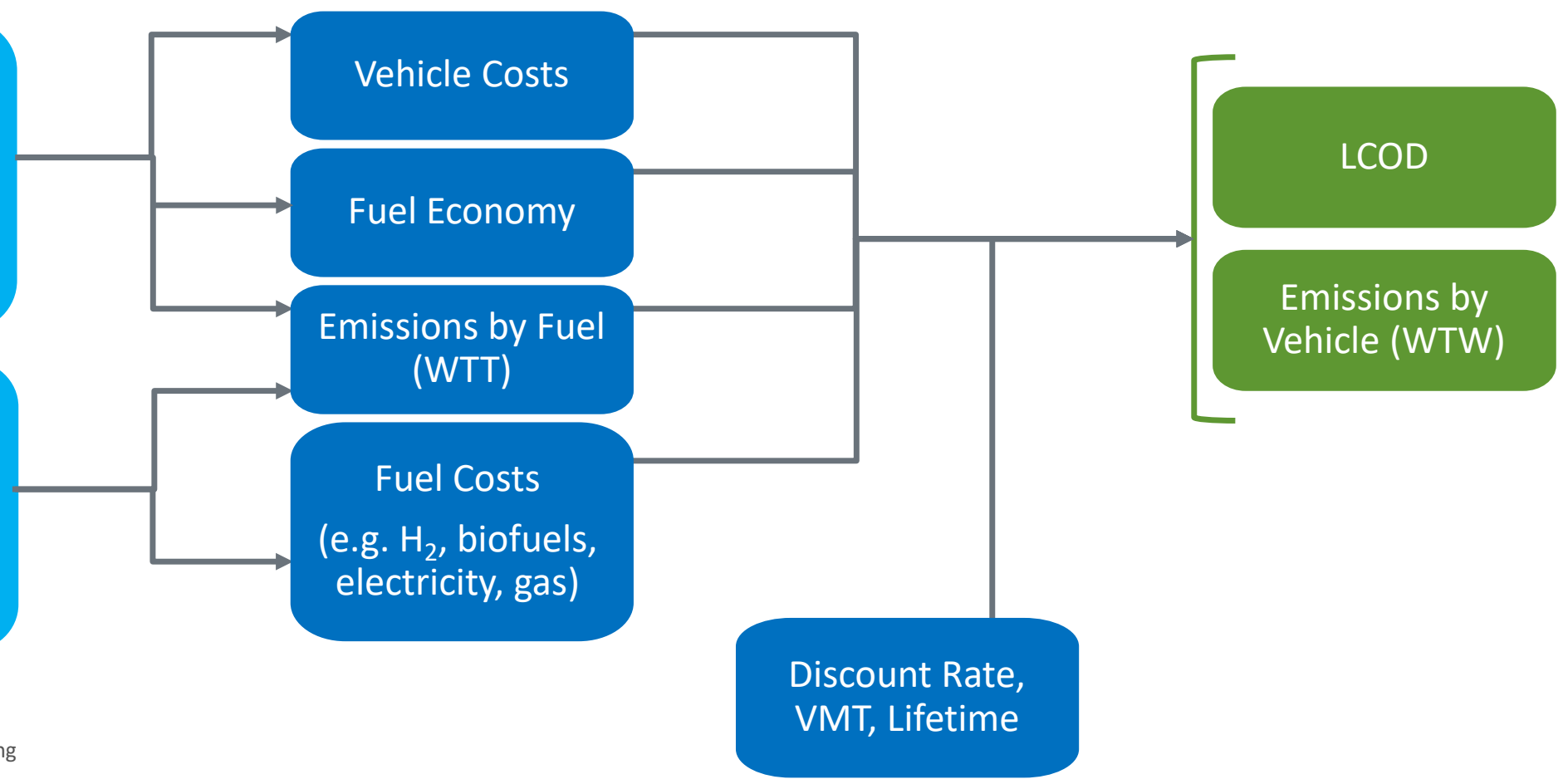




\section{Summary of ATB 2020 Data Sources}

\begin{tabular}{l|l}
\hline Input & Primary Sources \\
\hline $\begin{array}{l}\text { Vehicle Component Costs } \\
\text { (Fuel Cell, Battery Costs, etc.) }\end{array}$ & $\begin{array}{l}\text { Technology trajectories based on EERE data, public reports, and technology targets } \\
\text { and input into Autonomie modeling (Islam et al. 2020) }\end{array}$ \\
\hline Vehicle Costs and Fuel Economy & $\begin{array}{l}\text { Autonomie modeling (Islam et al. 2020); includes low-volume manufacturing } \\
\text { estimates for fuel cell electric vehicles }\end{array}$ \\
\hline $\begin{array}{l}\text { Fuel/ Blendstock Pathways } \\
\text { (Feedstock Costs, Operating Costs, etc.) }\end{array}$ & $\begin{array}{l}\text { Published EERE techno-economic analysis (TEA) reports for biofuel pathways; } \\
\text { H2A modeling and public reports for hydrogen pathways }\end{array}$ \\
\hline Fuel Costs & $\begin{array}{l}\text { Biofuels: Published EERE TEA reports } \\
\text { Hydrogen: H2A and HDSAM models, public reports } \\
\text { Gasoline, diesel, and ethanol: U.S. Energy Information Administration (EIA) and EIA } \\
\text { Annual Energy Outlook (AEO) } \\
\text { Electricity: EIA, AEO, and NREL Standard Scenarios (Cole et al. 2019) }\end{array}$ \\
\hline Fuel Emissions (WTT) & $\begin{array}{l}\text { GREET model } \\
\text { Discount Rate, VMT, Lifetime, and } \\
\text { Charging Infrastructure }\end{array}$ \\
\hline $\begin{array}{l}\text { Consistent with other EERE analyses, including Elgowainy et al. (2016); Melaina et al. } \\
\text { (2016); Bento, Roth, and Zuo (2018); and Lu (2006) }\end{array}$
\end{tabular}




\section{What is the value of the ATB?}

Transparency, Consistency, Credibility, and Accessibility

- Consolidates data from - and for use within - DOE's Sustainable Transportation analysis

- Summarizes data to high level needed for system-wide analysis

- Organizes data in highly structured format, enabling:

- Display of data in interactive charts

- Exploration, selection, and download of specific data

Data is free, publicly available, and easily accessible. 


\section{The ATB for electricity has six-year record of success.}

\section{Model Inputs}

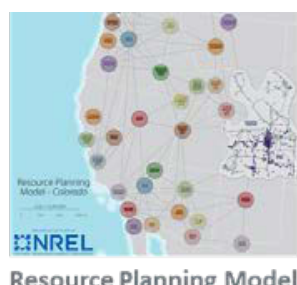

Resource Planning Model

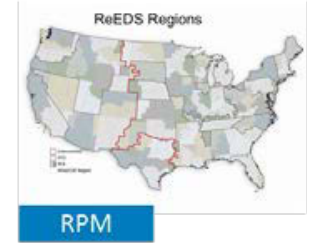

Regional Energy Deployment System

\section{Analyses}

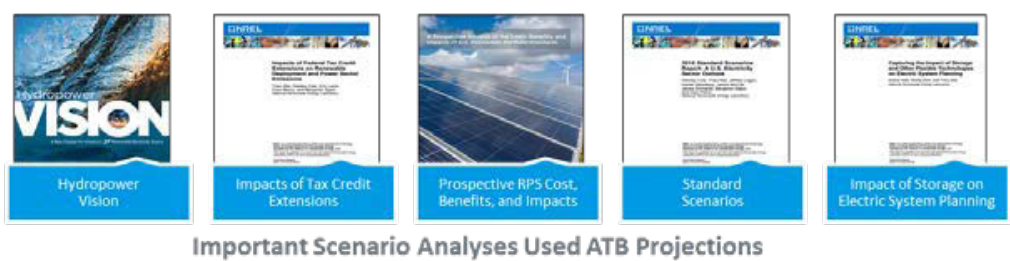

\section{External Users}

- Federal Agencies

- Consultants

- $\quad$ State Energy Offices
- Grid Operators

- Nonprofits

- International Organizations
- Utilities

- Academia

- Media 


\section{The ATB: Assumptions for Energy Systems Analysis}

\begin{tabular}{|clll}
\hline & \multicolumn{2}{c}{ Core ATB Data } \\
Base Year and & - Fuel Economy & - Financing Assumptions \\
Projected Data for... & - Vehicle Cost & - Levelized Cost of Driving \\
& - Fuel Cost & - Emissions \\
& - Fuel Emissions & \\
\hline
\end{tabular}

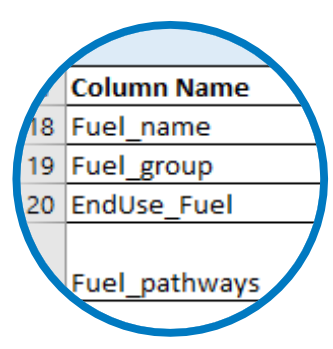

Spreadsheet

- Detailed citations

- Cost and performance projections, 2020-2050

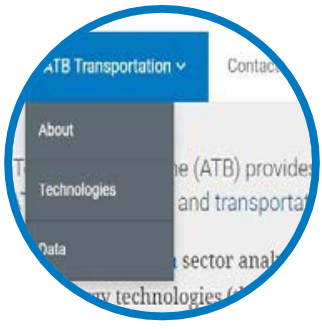

atb.nrel.gov

- User guidance

- Additional analyses

- Methodologies

- Comparison to other projections (e.g., EIA)

\section{ATB Product Suite}

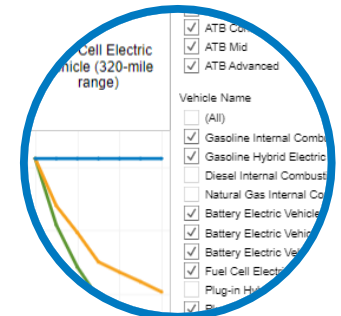

Tableau Workbook

- Summary of selected data (no calculations)

- Cost and performance projections, 2018-2050

- Interactive charts

- Visual exploration

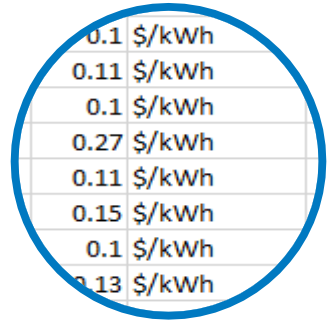

Formatted Data

- Database-friendly summaries

- Cost and performance projections, 20202050

- Structured format

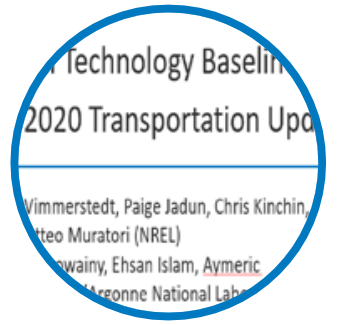

Presentation Slides

- Webinar presentation

- Summary presentation 
Technology Specifics:

Web Demo

- Fuels

- Vehicles 


\section{Annual Technology Baseline}

\section{About \\ Technologies \\ : Technologies}

Light-Duty Vehicles

Fuel Technologies

Data
- The 2020 Transportation Annual Technology Baseline (ATB) provides detailed cost and performance data, estimates, and assumptions for vehicle and fuel technologies in the United States.

- The Transportation ATB includes current and projected estimates through 2050 for light-duty vehicle technologies as well as conventional and alternative fuels, and it details the assumptions used to calculate those costs, such as gas and electricity prices, discount rates, and vehicle miles traveled. The 2020 Transportation ATB vehicle data are specifically for midsize passenger cars.

Explore the 2020 Transportation ATB:

VEHICLE TECHNOLOGIES

The Transportation ATB provides data in a series of interactive charts for either a single year or a trajectory out to 2050 showing:

- Fuel economy, reported in miles per gallon gasoline equivalent and representing how efficiently a vehicle converts fuel during operation

- Vehicle cost, which represents an estimated cost, including manufacturing costs plus profit, to the consumer purchasing a new vehicle.

- Levelized cost of driving, an indicator of the cost of operation over the vehicle lifetime on a per-mile basis

- Emissions, which represent the well-to-wheels emissions (including emissions from fuel production to vehicle operation). 


\section{Annual Technology Baseline}

\begin{tabular}{l} 
About \\
\hline Technologies \\
Light-Duty Vehicles \\
Fuel Technologies \\
On-Road Fuels \\
Jet Fuel
\end{tabular}

\section{Fuel Technologies}

The Transportation Annual Technology Baseline (ATB) provides price or cost, production, and emissions estimates for selected fuels.

The Transportation ATB presents fuels in three categories:

Marine Fuel

Data

$$
\text { ON-ROAD FUELS }
$$

$$
\text { JET FUELS }
$$

Diverse types of data are presented. Some fuel production pathways represent today's commercially available fuels, where data are available on high production volume market prices. Other data are estimated costs for current or future fuel production technologies, and may represent low or high volumes of production. In some cases, blendstock data are more readily accessible than fuel data.

A fuel is directly used in a vehicle, while a blendstock is one component of a fuel. Fuel price data include taxes for all fuels currently taxed, while blendstock data do not include taxes. Data for biofuels and hydrogen come from U.S. Department of Energy national laboratory analyses; data for petroleum-based fuels and conventional electricity sources come from other sources, primarily the U.S. Energy Information Administration. 


\begin{tabular}{l} 
About \\
\hline Technologies \\
\hline Light-Duty Vehicles \\
Fuel Technologies \\
On-Road Fuels \\
BoB \\
Diesel \\
Diesel Bine and Ethanol \\
Natural Gas Fuel \\
Electricity \\
Hydrogen \\
Jet Fuel \\
Marine Fuel \\
\hline Data
\end{tabular}

\begin{tabular}{|c|c|c|c|c|}
\hline Fuel Pathway & $\begin{array}{c}\text { Cellulosic } \\
\text { Biochemical } \\
\text { Ethanol }\end{array}$ & $\begin{array}{c}\text { Cellulosic } \\
\text { Thermochemical } \\
\text { Ethanol }\end{array}$ & $\begin{array}{c}\text { Cellulosic } \\
\text { Biochemical } \\
\text { Ethanol Low } \\
\text { Volume }\end{array}$ & $\begin{array}{l}\text { Starch } \\
\text { Ethanol }\end{array}$ \\
\hline Scenario & $\begin{array}{c}\text { Future Model, } \\
\text { High Vol }\end{array}$ & $\begin{array}{c}\text { Future Model, } \\
\text { High Vol }\end{array}$ & $\begin{array}{l}\text { Future Model, Low } \\
\text { Vol }\end{array}$ & $\begin{array}{l}\text { Current } \\
\text { Market }\end{array}$ \\
\hline $\begin{array}{r}\text { Plant Gate Fuel Price } \\
\text { (\$/gge) }\end{array}$ & $3.75-3.96$ & 3.65 & $5.31-5.52$ & 2.25 \\
\hline $\begin{array}{r}\text { Fixed Capital } \\
\text { Investment } \\
(\$)\end{array}$ & $417,000,000$ & $563,000,000$ & $479,000,000$ & - \\
\hline $\begin{array}{r}\text { Fixed Operating Cost } \\
(\$ / y r)\end{array}$ & $12,500,000$ & $27,100,000$ & $12,500,000$ & - \\
\hline $\begin{array}{r}\text { Mature Industry } \\
\text { Feedstock } \\
\text { Production Cost } \\
(\$ / y r)\end{array}$ & $54,200,000$ & $45,800,000$ & $75,000,000$ & - \\
\hline $\begin{array}{r}\text { Other (non- } \\
\text { feedstock) Variable } \\
\text { Operating cost } \\
(\$ / y r)\end{array}$ & $25,000,000$ & $4,170,000$ & $34,400,000$ & - \\
\hline $\begin{array}{l}\text { Power Sales Revenue } \\
\qquad(\$ / y r)\end{array}$ & $6,250,000$ & - & $6,250,000$ & - \\
\hline $\begin{array}{r}\text { Throughput Capacity } \\
\text { (dt/day) }\end{array}$ & 2,200 & 2,200 & 2,200 & - \\
\hline $\begin{array}{r}\text { Total Product Yield } \\
\text { (Gal/dt) }\end{array}$ & $79.00-84.00$ & 84.00 & $71.00-75.00$ & - \\
\hline
\end{tabular}




\begin{tabular}{l}
\hline About \\
\hline Technologies \\
\hline Light-Duty Vehicles \\
Fuel Technologies \\
On-Road Fuels \\
Jet Fuel \\
Marine Fuel \\
Data
\end{tabular}

\begin{tabular}{|c|c|c|}
\hline Fuel Name & Alt Jet & Conventional Jet \\
\hline Fuel Pathway & Biofuel (Jet) & $\begin{array}{l}\text { Conventional Jet } \\
\text { Fuel }\end{array}$ \\
\hline Scenario & $\begin{array}{l}\text { Future Model, High } \\
\text { Vol }\end{array}$ & Current Market \\
\hline $\begin{array}{r}\text { Fuel Price } \\
\text { (\$/gge) }\end{array}$ & $3.38-5.63$ & 1.95 \\
\hline $\begin{array}{r}\text { Fixed Capital Investment } \\
(\$)\end{array}$ & $\begin{array}{r}365,000,000- \\
521,000,000\end{array}$ & - \\
\hline $\begin{array}{r}\text { Fixed Operating Cost } \\
\qquad(\$ / y r)\end{array}$ & $15,600,000-26,100,000$ & - \\
\hline $\begin{array}{r}\text { Mature Industry Feedstock Production cost } \\
(\$ / \mathrm{yr})\end{array}$ & $56,300,000-69,800,000$ & - \\
\hline $\begin{array}{r}\text { Other (non-feedstock) Variable Operating } \\
\text { Cost } \\
(\$ / y r)\end{array}$ & $26,100,000-49,000,000$ & - \\
\hline $\begin{array}{r}\text { Power Sales Revenue } \\
(\$ / \mathrm{yr})\end{array}$ & $5,210,000$ & - \\
\hline $\begin{array}{r}\text { Throughput Capacity } \\
\text { (dt/day) }\end{array}$ & 2,200 & - \\
\hline $\begin{array}{l}\text { Total Product Yield } \\
\text { (Gal/dt) }\end{array}$ & $50.00-80.00$ & - \\
\hline $\begin{array}{r}\text { Coproducts Sales Revenue } \\
(\$ / \mathrm{yr})\end{array}$ & $5,210,000-24,000,000$ & - \\
\hline $\begin{array}{l}\text { Co2e Emissions (Well to Tank) } \\
\text { (g/mmBtu) }\end{array}$ & $-55,900-5,280$ & 14,400 \\
\hline $\begin{array}{r}\text { NOX Emissions (Well to Tank) } \\
\text { (g/mmBtu) }\end{array}$ & - & 26.70 \\
\hline
\end{tabular}


Key assumptions and

references are detailed at

the bottom of each fuel

web page.

\section{Example of Documented Assumptions on Web Page}

\section{Key Assumptions}

The data and estimates presented here are based on the following key assumptions:

- The high and low fuel prices are associated with particular years; because we do not provide a time-series trajectory, we show fuel price at a frozen level for all years so we can offer a range of fuel price values. In the levelized cost of driving and emissions charts, this approach clearly distinguishes effects of fuels from those of vehicle technologies because fuels remain constant while vehicle technologies change over time.

- The fuel price for hydrogen includes the production cost and the cost of infrastructure for hydrogen delivery and dispensing. We do not add a tax to hydrogen, because hydrogen is not currently taxed.

- Current hydrogen prices are highly variable due to the nascent market maturity. Fuel costs are often included in leases for fuel cell electric vehicles, are not paid by the user at the pump. The hydrogen price at the pump in California is approximately $\$ 16.50 / \mathrm{kg}$ (California Energy Commission and California Air Resources Board 2019). For the ATB, we base the Current market scenario on modeled production costs and current delivery and dispensing costs, as described below.

- The delivery and dispensing cost for the steam methane reforming Current market scenario is $\$ 12.53 /$ gge of the $\$ 13.70 / g g e$. The estimate is the average of the range of current cost estimates from Rustagi et al. (2018) of $\$ 12.07 /$ gge- $\$ 12.99 /$ gge (corresponding to $\$ 11.80 / \mathrm{kg}-\$ 12.70 / \mathrm{kg}$ in $2017 \$$ from the original source). This range corresponds to the costs of hydrogen delivery and dispensing from two common station types today- a $180 \mathrm{~kg} /$ day station supplied by a gaseous tube trailer, and a $350 \mathrm{~kg} /$ day station supplied by a liquid tanker.

- The delivery and dispensing cost for the other non-Current market scenario pathways is estimated at $\$ 10.89 /$ gge in the Current Modeled technology, Current Volume scenario, based on mid-volume tubetrailer delivery and low-volume manufacturing; \$6.27/gge in the Current Modeled, High Volume scenario based on high-volume tube-trailer delivery and high-volume manufacturing; and \$2.05/gge in the Future Modeled, High Volume scenario, based on the ultimate, high-volume hydrogen delivery and dispensing cost target. All delivery costs were modeled in the Hydrogen Delivery Scenario Analysis Model 3.2 (Argonne National Laboratory 2019c) and are based on gaseous hydrogen delivery. All values are converted based on $1.019 \mathrm{gge} / \mathrm{kg}$ hydrogen and updated to 2018 dollars (the delivery and dispensing costs above correspond to $\$ 10.65 / \mathrm{kg}, \$ 6.13 / \mathrm{kg}$, and $\$ 2.00 / \mathrm{kg}$ in $2016 \$$ from HDSAM, respectively). 


\section{Annual Technology Baseline}

About

Technologies

Light-Duty Vehicles

Fuel Technologies

Data

\section{Technologies}

The 2020 Transportation Annual Technology Baseline (ATB) provides detailed cost and performance data, estimates, and assumptions for vehicle and fuel technologies in the United States.

- The Transportation ATB includes current and projected estimates through 2050 for light-duty vehicle technologies as well as conventional and alternative fuels, and it details the assumptions used to calculate those costs, such as gas and electricity prices, discount rates, and vehicle miles traveled. The 2020 Transportation ATB vehicle data are specifically for midsize passenger cars.

Explore the 2020 Transportation ATB:

$$
\text { VEHICLE TECHNOLOGIES }
$$

\section{FUEL TECHNOLOGIES}

The Transportation ATB provides data in a series of interactive charts for either a single year or a trajectory out to 2050 showing:

- Fuel economy, reported in miles per gallon gasoline equivalent and representing how efficiently a vehicle converts fuel during operation

- Vehicle cost, which represents an estimated cost, including manufacturing costs plus profit, to the consumer purchasing a new vehicle.

- Levelized cost of driving, an indicator of the cost of operation over the vehicle lifetime on a per-mile basis

- Emissions, which represent the well-to-wheels emissions (including emissions from fuel production to vehicle operation). 


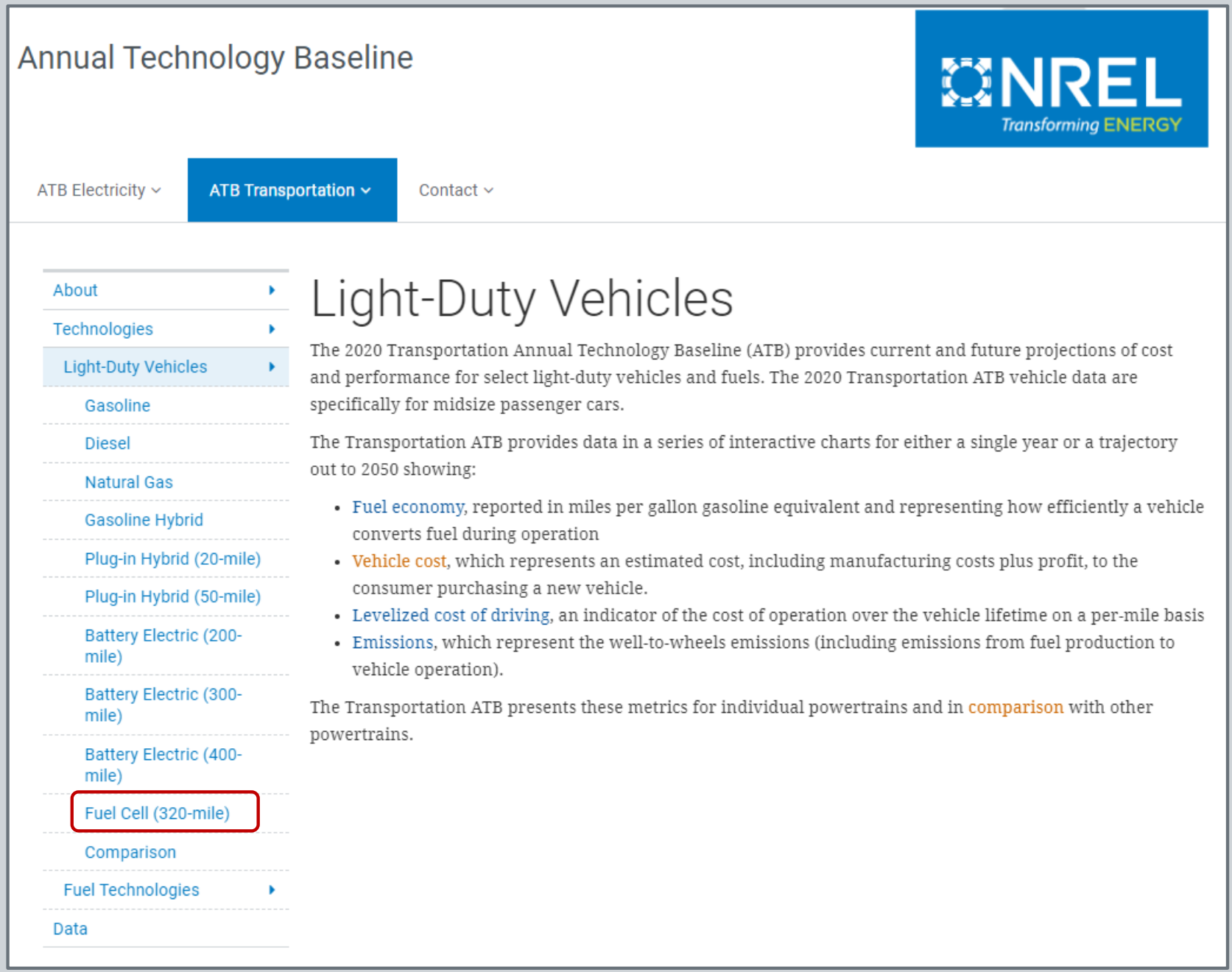




\section{Cost, Fuel Economy: FCEV Example}
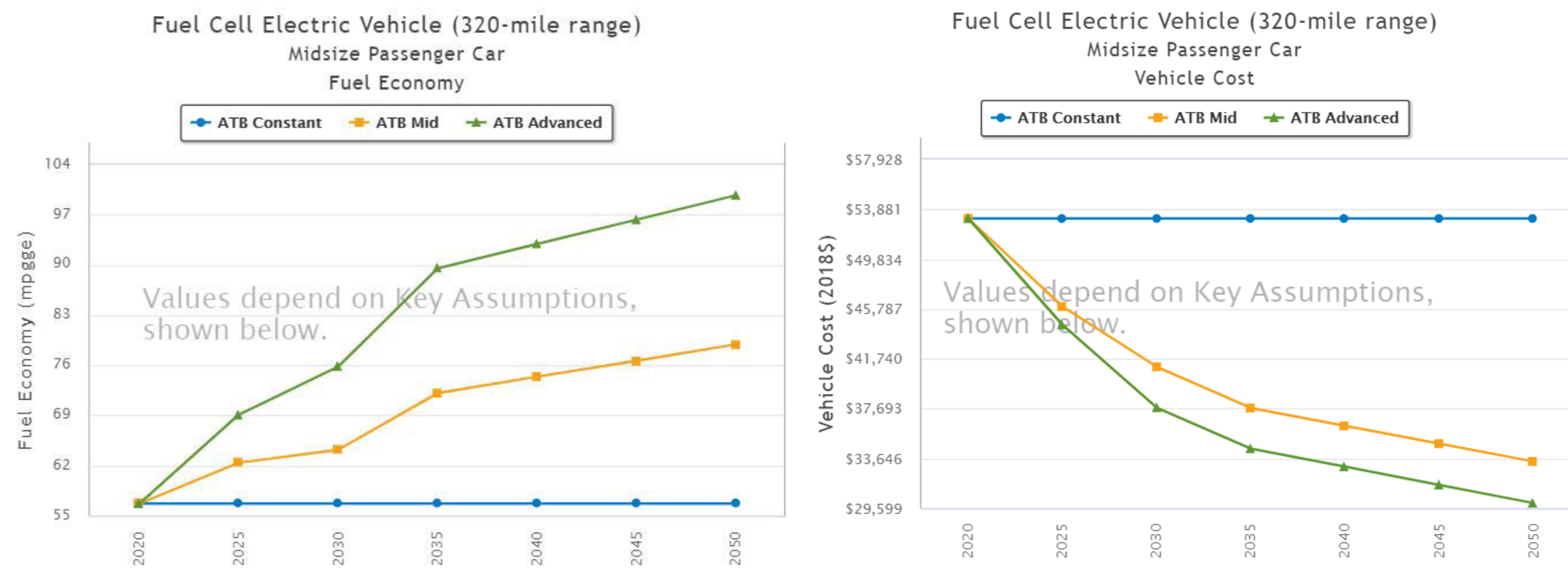

ATB Constant: Technologies do not advance from 2020 levels.

ATB Mid: Technologies improve at moderate levels, with continued industry growth and R\&D investment.

ATB Advanced: Technology advances occur with breakthroughs, increased public and private R\&D investment, and other market conditions that lead to significantly improved cost and performance levels but do not necessarily reach the full technical potential. 


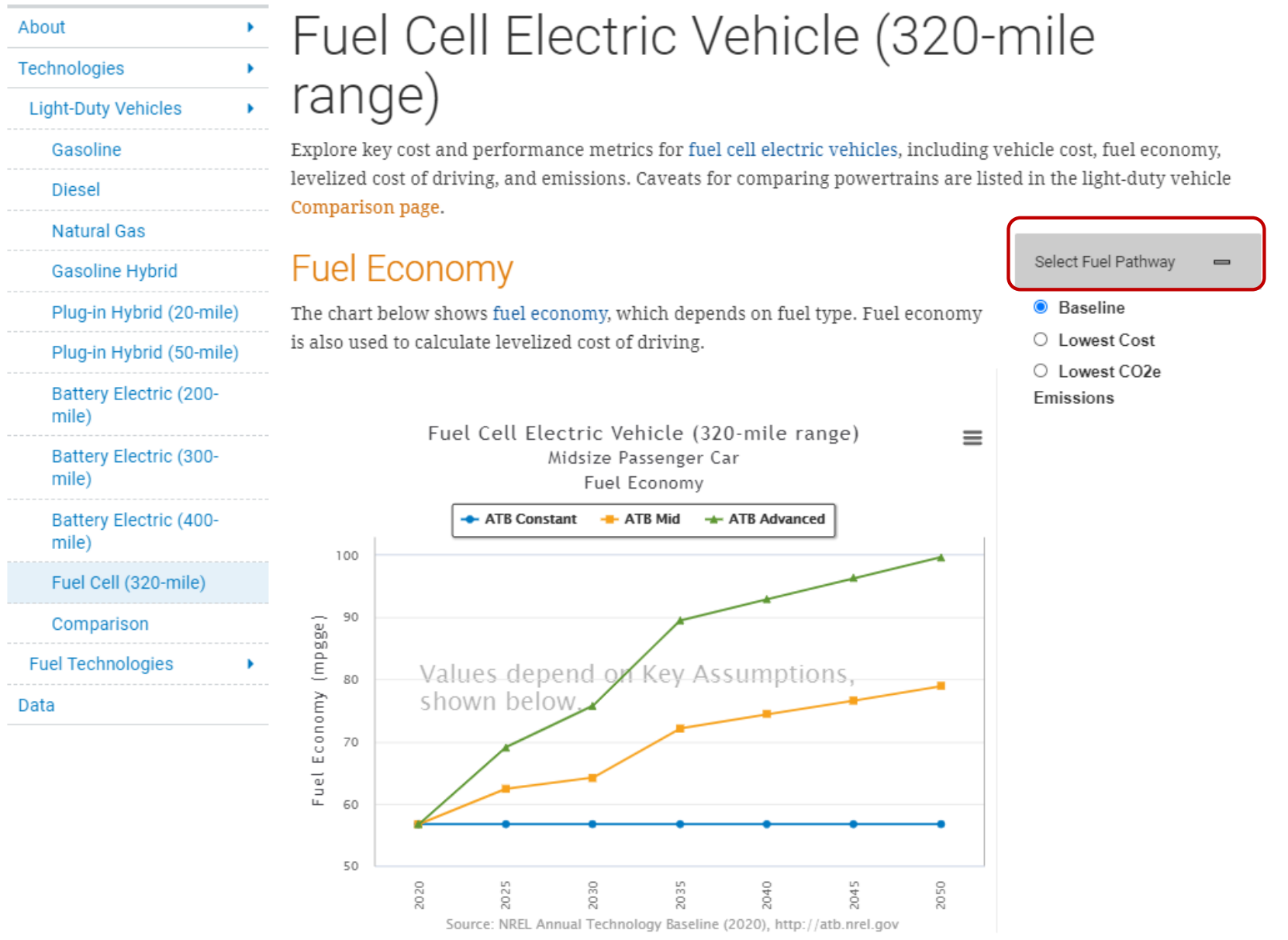




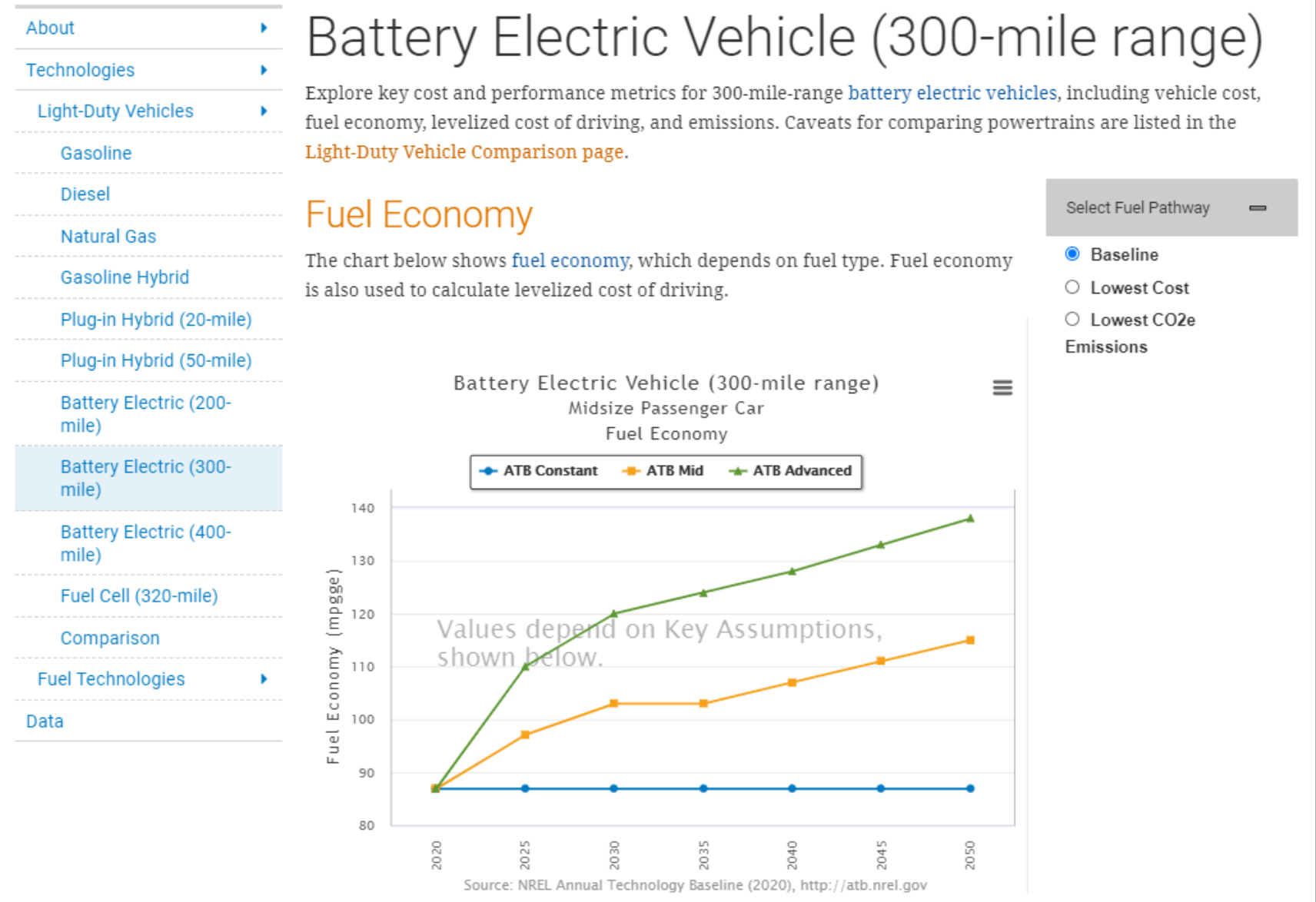




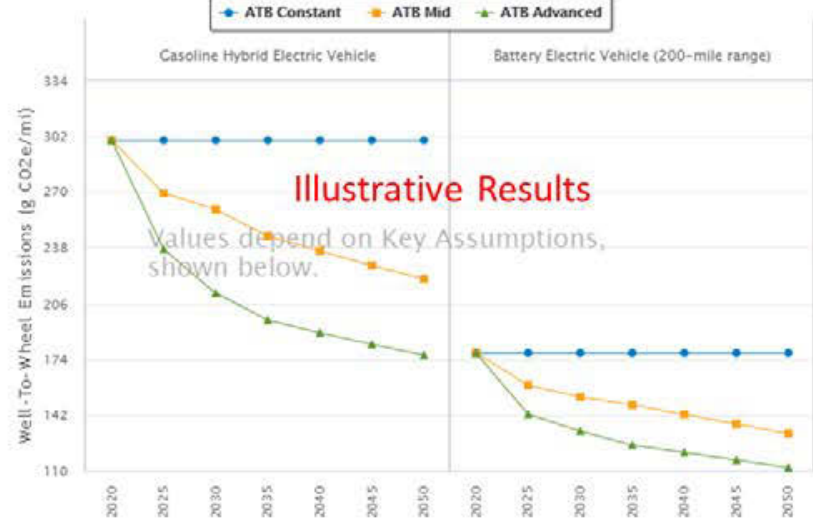

Trajectories show the levelized cost of driving or emissions for a given powertrain on a per mile basis.

Estimates are calculated using a selected fuel pathway, for which the cost and emissions are held constant over time.

Therefore, changes over time are attributable only to projected vehicle cost and performance. This approach clearly distinguishes effects of fuels from those of vehicle technologies because fuels remain constant while vehicle technologies change over time.

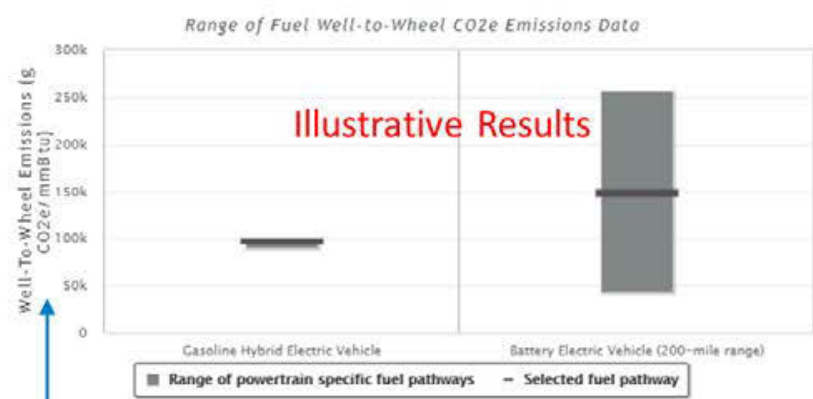

\section{Range of Fuel Data}

Fuels for this powertrain

Highest Value (all fuels)

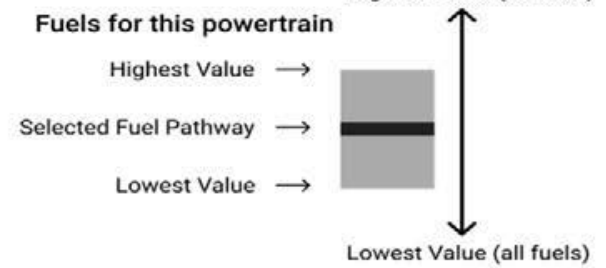

Fuel data shows well-to-wheels emissions (with the emissions chart) and cost (with the LCOD chart) for both the selected fuel (black line) and the range of fuels in the ATB (grey for emissions bars/green for cost).

The fuel cost per gge and emissions per mmBtu are constant over time, clearly distinguishing the effect of fuels from those of vehicle technologies. Different fuel scenarios can be selected using the fuel pathway selector.

Hovering over the bar will report the cost $(\$ / g g e)$ or emissions $(\mathrm{g} / \mathrm{mmBtu})$ for the selected fuel and the maximum and minimum costs or emissions of the available fuels for the relevant powertrain. 


\section{Selected Fuel Pathways}

Selected Fuel Pathways by Powertrain

\begin{tabular}{|c|c|c|c|}
\hline Powertrain & $\begin{array}{l}\text { Baseline Fuel } \\
\text { Pathway }\end{array}$ & $\begin{array}{l}\text { Lowest Cost Fuel } \\
\text { Pathway }\end{array}$ & $\begin{array}{l}\text { Lowest } \mathrm{CO}_{2} \mathrm{e} \\
\text { Emissions Fuel } \\
\text { Pathway }\end{array}$ \\
\hline $\begin{array}{l}\text { Gasoline internal combustion } \\
\text { engine vehicle, hybrid electric } \\
\text { vehicle, charge-sustaining } \\
\text { plug-in hybrid electric vehicle }\end{array}$ & $\begin{array}{l}\text { Conventional } \\
\text { gasoline (E10) } \\
\text { with starch } \\
\text { ethanol }\end{array}$ & $\begin{array}{l}\text { Conventional } \\
\text { gasoline (E10) with } \\
\text { starch ethanol }\end{array}$ & $\begin{array}{l}\text { Reformulated E15 } \\
\text { gasoline with } \\
\text { cellulosic } \\
\text { thermochemical } \\
\text { ethanol }\end{array}$ \\
\hline $\begin{array}{l}\text { Diesel internal combustion } \\
\text { engine vehicle }\end{array}$ & $\begin{array}{l}\text { Conventional low- } \\
\text { sulfur diesel }\end{array}$ & $\begin{array}{l}\text { Conventional low- } \\
\text { sulfur diesel ( } 2050 \\
\text { low price) }\end{array}$ & Biofuel (diesel) \\
\hline $\begin{array}{l}\text { Compressed natural gas } \\
\text { internal combustion engine } \\
\text { vehicle }\end{array}$ & Natural gas & Natural gas & Natural gas \\
\hline $\begin{array}{l}\text { BEV, charge-depleting plug-in } \\
\text { hybrid electric vehicle }\end{array}$ & $\begin{array}{l}\text { Plug-in electric } \\
\text { vehicle charging } \\
\text { electricity,national } \\
\text { grid mix }\end{array}$ & $\begin{array}{l}\text { Plug-in electric } \\
\text { vehicle charging } \\
\text { electricity, future } \\
\text { low RE } \\
\text { penetration grid } \\
\text { mix }\end{array}$ & $\begin{array}{l}\text { Plug-in electric } \\
\text { vehicle charging } \\
\text { electricity, future } \\
\text { high RE } \\
\text { penetration grid } \\
\text { mix }\end{array}$ \\
\hline Fuel cell electric vehicle & $\begin{array}{l}\text { Steam methane } \\
\text { reforming } \\
\text { (Current Modeled, } \\
\text { Current Volume) }\end{array}$ & $\begin{array}{l}\text { Steam methane } \\
\text { reforming (Future } \\
\text { Modeled, High } \\
\text { Volume) }\end{array}$ & $\begin{array}{l}\text { Low-temperature } \\
\text { electrolysis (Future } \\
\text { Modeled, High } \\
\text { Volume) }\end{array}$ \\
\hline
\end{tabular}


Fuel Cell Electric Vehicle (320-mile range)

Midsize Passenger Car

CO2e Emissions (Baseline Fuel)

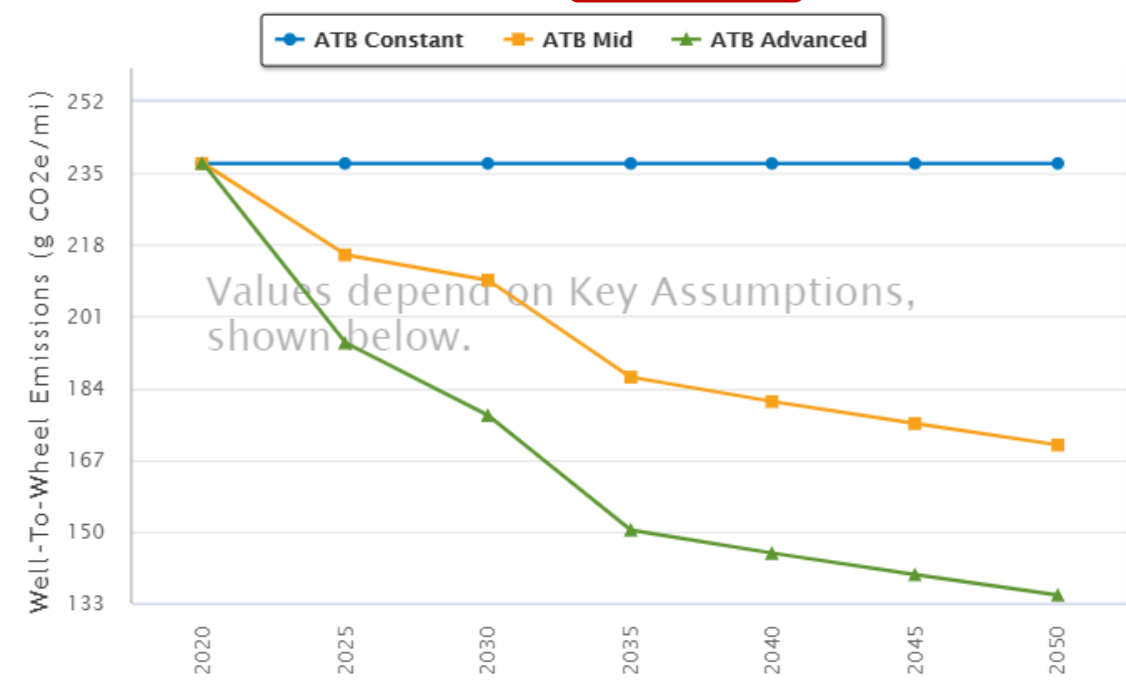

Range of Fuel Well-to-Wheel CO2e Emissions Data
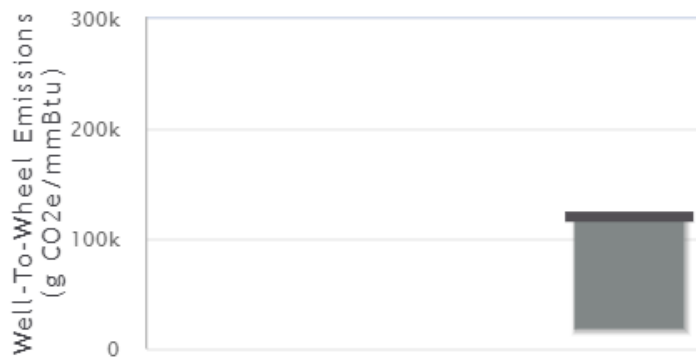

Range of powertrain specific fuel pathways
Fuel Cell Electric Vehicle (320-mile range)

Midsize Passenger $\mathrm{Car}$

CO2e Emissions (Lowest CO2e Emissions Fuel)

$\rightarrow$ ATB Constant $\rightarrow$ ATB Mid $₫$ ATB Advanced

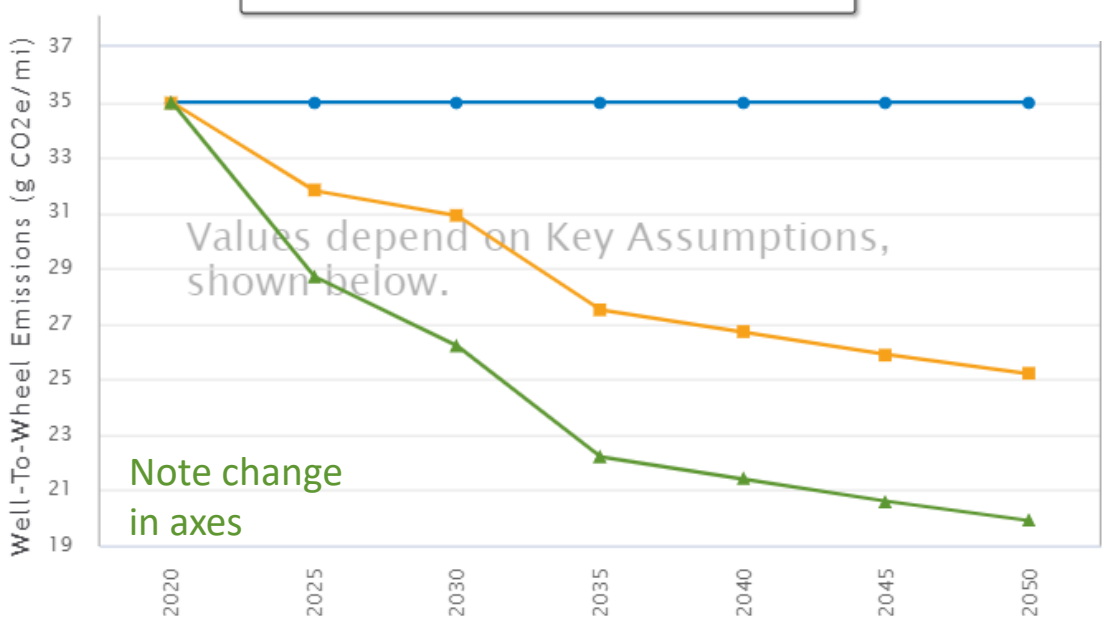

Range of Fuel Well-to-Wheel CO2e Emissions Data
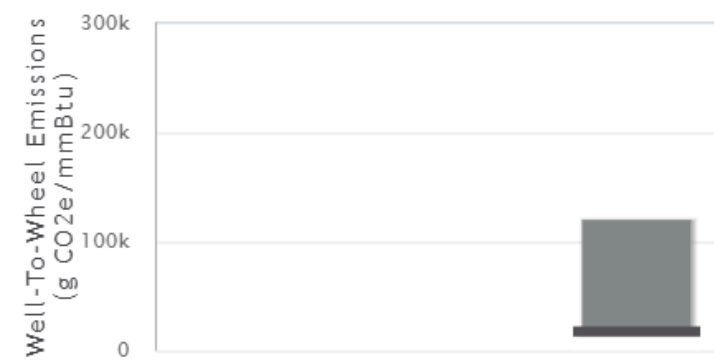

Range of powertrain specific fuel pathways 
Key assumptions and

references detailed at the bottom of each vehicle web page.

\section{Example of Documented Assumptions on Web Page}

Key Assumptions

The data and estimates presented here are based on the following key assumptions:

- The cost and fuel economy trajectories for fuel cell electric vehicles are based on estimates of commercially available technologies in the respective years. Estimates of fuel cell costs and hydrogen storage vessel costs were based on an assumption of low production volume manufacturing today that gradually increases to high production volume manufacturing by 2050 .

These costs were adapted from James et al. (2018) and Adams, et al. (2019).

All other vehicle component assumptions (e.g. lightweighting and aerodynamic improvements over time) are consistent with Islam et al. (2020). The ATB Mid trajectory corresponds to the Base performance, Low technology progress case. The ATB Advanced trajectory corresponds to the Base performance, High technology progress case. The ATB Constant trajectory is set to the 2020 values in the Base performance, Low technology case and held constant through 2050.

- The assumed fuel cell and hydrogen storage tank cost trajectories can be found in the definition for fuel cell electric vehicles.

- Fuel cell electric vehicles are currently manufactured at low production volume, and are available for sale or lease in the US for approximately $\$ 58,300$ or $\$ 379-\$ 389 /$ month. Today, the purchase or lease of the vehicle commonly includes access to hydrogen fuel for free for up to 3 years or $\$ 13,000-\$ 15,000$ (Honda 2020; Hyundai 2020; Baronas and Achtelik 2019).

- The Transportation ATB presents estimates for a representative, single size of light-duty vehicle (midsize); we do not account for variations in make, model, and trim or for pricing incentives or geographic heterogeneity that influence prices in the market. As a result, representative values shown here may differ from specific models available on the market. 


\section{Multi-Powertrain View Enables Comparison}

\section{Light-Duty Vehicle Comparison \\ Midsize Passenger Car \\ Fuel Economy}

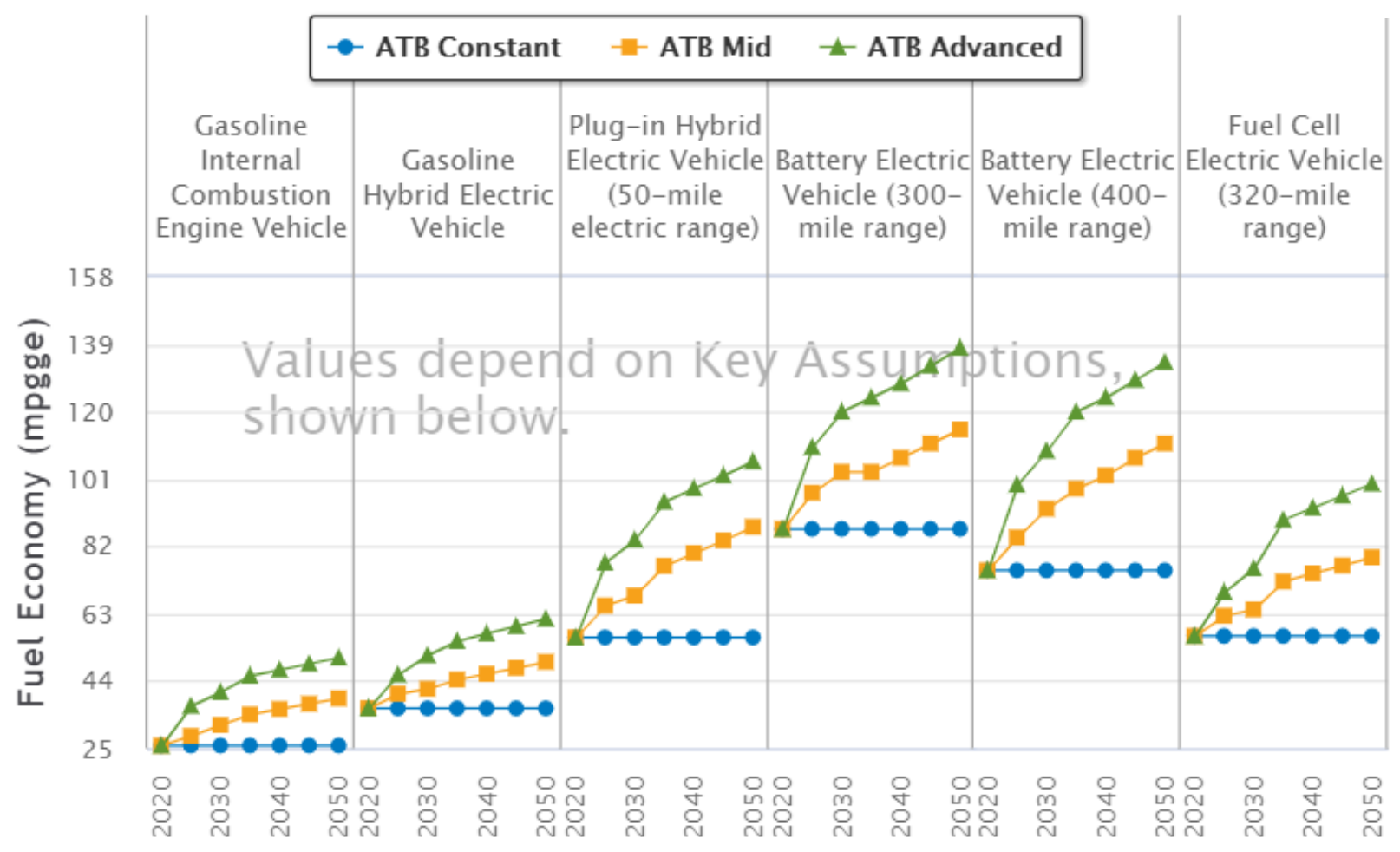




\section{Light-Duty Vehicle Comparison Midsize Passenger Car \\ Vehicle Cost}

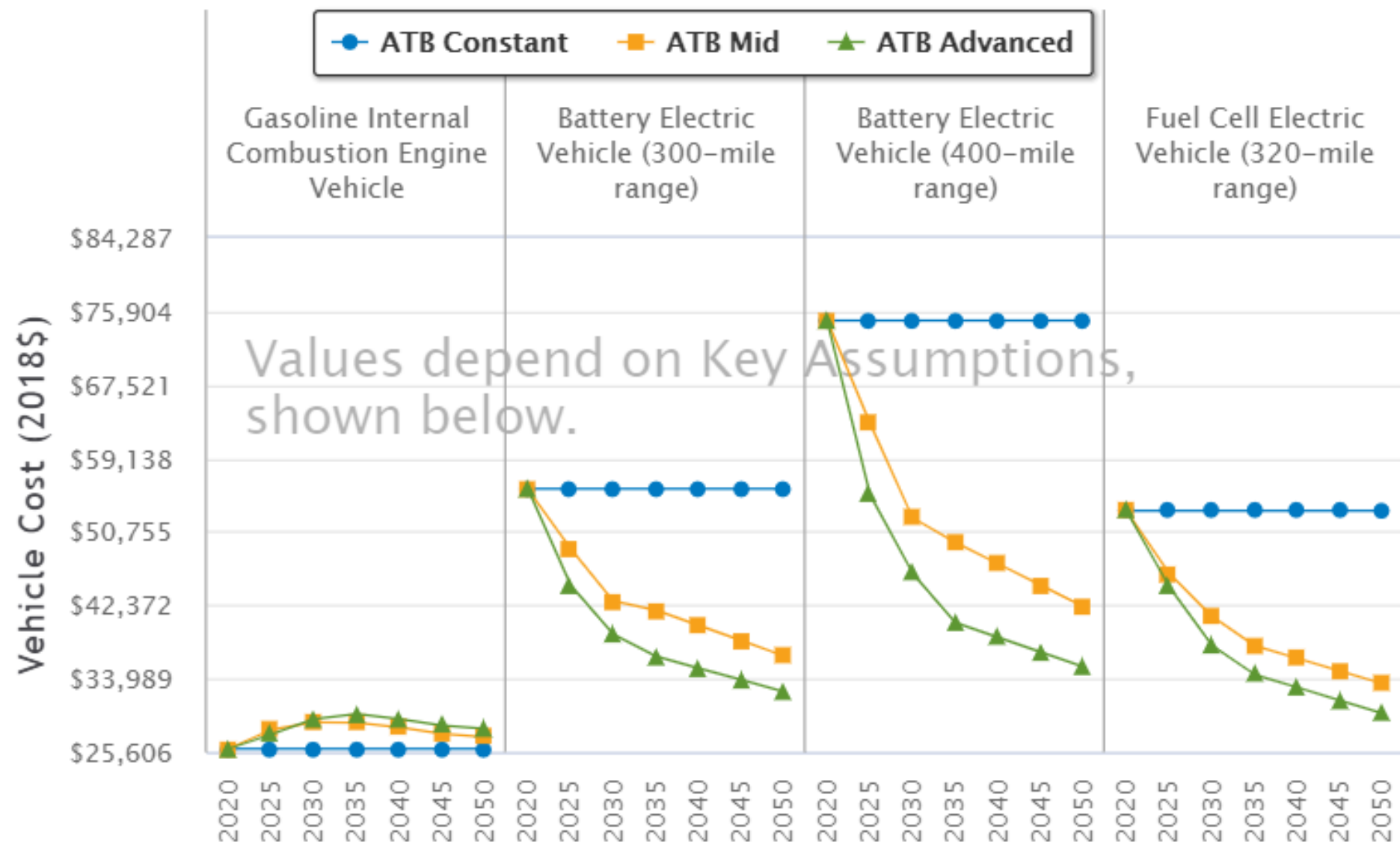




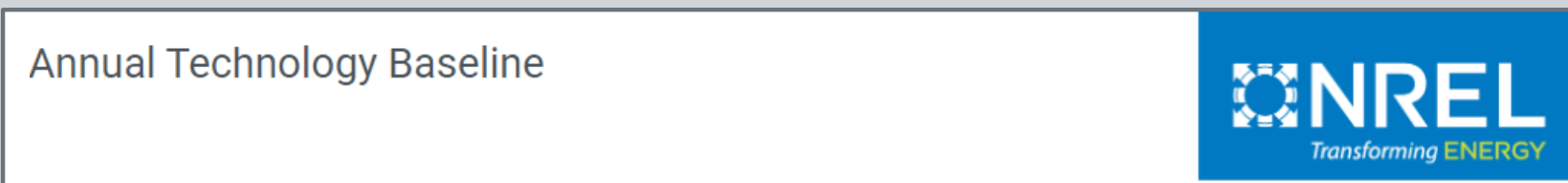

\section{ATB Electricity $\vee \quad$ ATB Transportation $\vee$ Contact $\vee$

\begin{tabular}{l}
\hline About \\
Definitions \\
Literature Context \\
References \\
\hline Technologies \\
\hline Data \\
\hline
\end{tabular}

\section{Definitions}

Definitions of common terms in the 2020 Transportation ATB are presented below.

See definitions for:

$$
\text { VEHICLES }
$$

\section{Vehicles}

\section{Battery Electric Vehicles}

Battery electric vehicles (BEVs) use a battery pack to store the electrical energy that powers the motor. The batteries are charged by plugging the vehicle into an electric power source (DOE 2019).

For additional background, see the Alternative Fuels Data Center's All-Electric Vehicles.

The battery cost assumptions used in the Annual Technology Baseline vehicle cost trajectories are shown below and are presented at the battery pack level. The ATB Mid trajectory corresponds with the Base performance, Low technology progress case in Islam et al. (2020), which reaches around $\$ 120 /$ kilowatt-hour in 2050. The ATB Advanced trajectory follows the Base performance, High technology progress case from Islam et al. (2020) which reaches around \$80/kilowatt-hour in 2050, consistent with goals from the Vehicle Technologies Office (Boyd 2018). The ATB Constant trajectory is held constant at the 2020 value for ATB Mid. Costs are shown are for usable energy.

Note that estimates used in the ATB Advanced trajectory are higher than some recent battery cost estimates from other references (Lutsey and Nicholas 2019; Kah 2019; BloombergNEF 2019). Some variations may be attributed to differences in the level of reporting; the Transportation ATB presents battery costs for usable energy at the pack level. The cost estimates are consistent with the U.S. Department of Energy Vehicle 
,

Data

\section{Tableau Workbook}

View a Tableau workbook to further explore the data, including levelized cost of driving and emissions estimates with additional fuel pathways.

\begin{tabular}{l|l|l|l|l|l|l|l|l|l|l|l|l|l}
-1 & Cost Trajectory & Cost Year & Fuel Econ. Trajectory & Fuel Econ Year & LCOD+Fuels Trajectory & LCOD Year & Emissions+Fuels Trajectory & Emissions Year & Fuels Comp View & Powertrain View (1 Fuel)
\end{tabular}

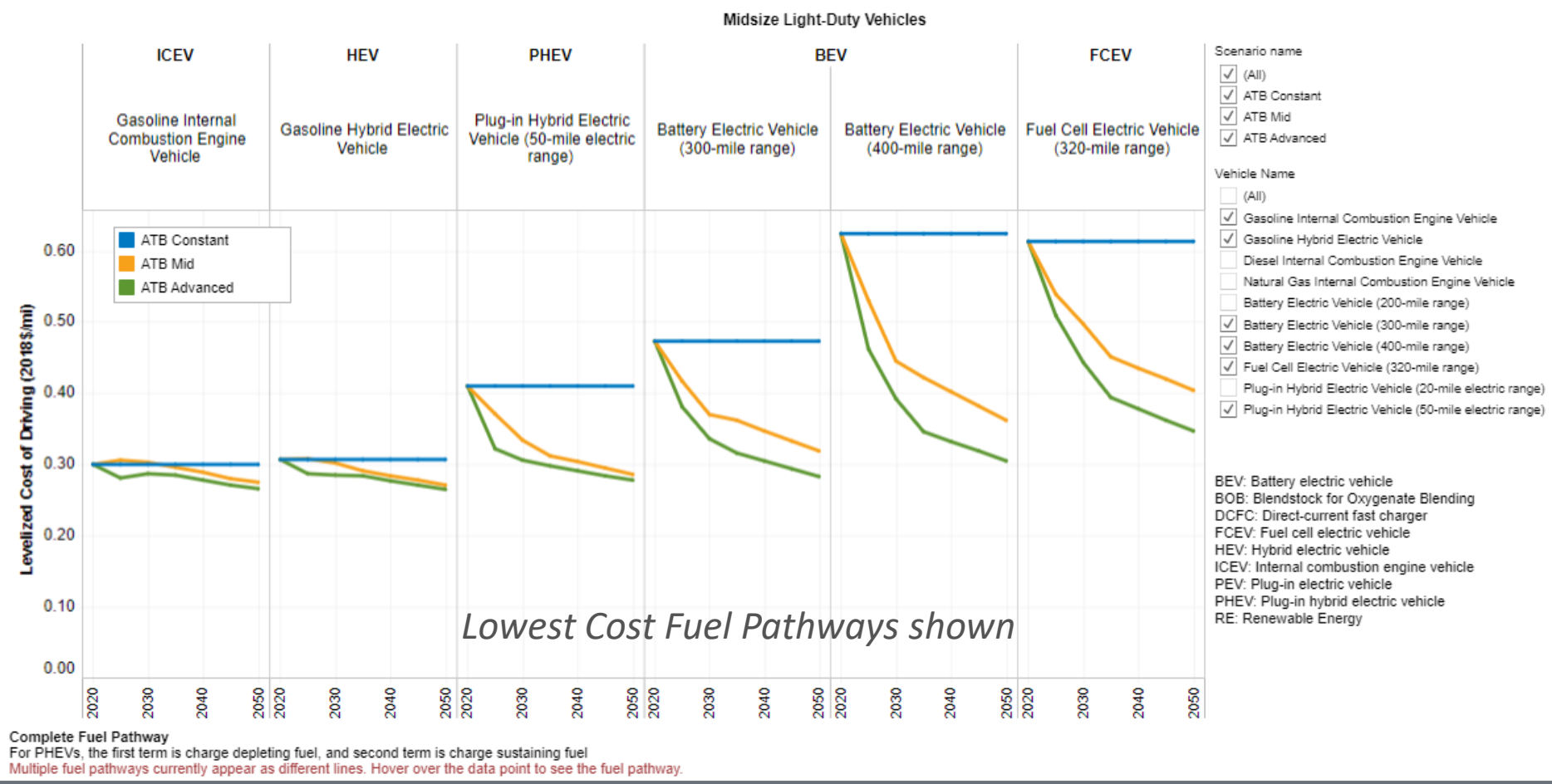




\title{
Conclusion
}

\author{
The ATB Vision
}




\section{The Vision}

The ATB-a flagship analytic product-facilitates access to credible, consistent, transparent, timely, relevant, and public data about current and future energy technologies and systems from a lab/DOE perspective for a large and diverse audience.

Please let us know your comments on what additional data sets or data metrics would be useful. 


\section{Sign up for} updates!
To receive occasional email updates and announcements about the Annual Technology Baseline, sign up at atb.nrel.gov/contact/register. 


\section{Acknowledgements}

This work was funded by the U.S. Department of Energy's

Strategic Priorities and Impact Analysis portfolio, Hydrogen and Fuel Cell Technologies Office, Vehicle Technologies Office, and Bioenergy Technologies Office, all within the Office of Energy Efficiency and Renewable Energy. 


\section{Thank You!}

Questions? Please let us know at https://atb.nrel.gov/contact/.

\section{www.nrel.gov}

NREL/PR-6A20-77319

This project is led by the National Renewable Energy Laboratory, operated by Alliance for Sustainable Energy, LLC, for the U.S. Department of Energy (DOE) under Contract No. DE-AC36-08GO28308. Funding provided by the U.S. Department of Energy Office of Energy Efficiency and Renewable Energy Strategic Priorities and Impacts Analysis, Bioenergy Technologies Office, Fuel Cell Technologies Office, and Vehicle Technologies Office. The views expressed in this presentation do not necessarily represent the views of the DOE or the U.S. Government. The U.S.

Government retains and the publisher, by accepting the article for publication, acknowledges that the U.S.

Government retains a nonexclusive, paid-up, irrevocable, worldwide license to publish or reproduce the published form of this work, or allow others to do so, for U.S. Government purposes. 


\section{References}

Bento, Antonio, Kevin Roth, and Yiou Zuo. 2018. "Vehicle Lifetime and Scrappage Behavior: Trends in the U.S. Used Car Market." The Energy Journal 39(1). https://doi.org/10.5547/01956574.39.1.aben.

Cole, Wesley, Nathaniel Gates, Trieu Mai, Daniel Greer, and Paritosh Das. 2019. 2019 Standard Scenarios Report: A U.S. Electricity Sector Outlook. Golden, CO: National Renewable Energy Laboratory. NREL/TP-TP-6A20-74110. https://doi.org/10.2172/1580330.

Elgowainy, Amgad, Jeongwoo Han, Jacob Ward, Fred Joseck, David Gohlke, Alicia Lindauer, Todd Ramsden, et al. 2016. Cradle-toGrave Lifecycle Analysis of U.S. Light-Duty Vehicle-Fuel Pathways: A Greenhouse Gas Emissions and Economic Assessment of Current (2015) and Future (2025-2030) Technologies. Argonne National Laboratory. ANL/ESD-16/7. Rev. 1.

https://doi.org/10.2172/1324467.

Islam, Ehsan Sabri, Ayman Moawad, Namdoo Kim, and Aymeric Rousseau. 2020. Energy Consumption and Cost Reduction of Future Light-Duty Vehicles Through Advanced Vehicle Technologies: A Modeling Simulation Study Through 2050. Argonne National Laboratory. ANL/ESD-19/10/. https://www.autonomie.net/pdfs/ANL - Islam - 2020 - Energy Consumption and Cost Reduction of Future Light-Duty Vehicles through Advanced Vehicle Technologies A Modeling Simulation Study Through 2050.pdf.

Lu, S. 2006. Vehicle Survivability and Travel Mileage Schedules. National Highway Traffic Safety Administration (NHTSA) National Center for Statistics and Analysis. DOT HS 809 952. https://crashstats.nhtsa.dot.gov/Api/Public/ViewPublication/809952

Melaina, Marc, Brian Bush, Joshua Eichman, Eric Wood, Dana Stright, Venkat Krishnan, David Keyser, et al. 2016. National Economic Value Assessment of Plug-in Electric Vehicles: Volume I. Golden, CO: National Renewable Energy Laboratory. NREL/TP5400-66980. https://doi.org/10.2172/1338175. 


\title{
Acronyms and Abbreviations
}

\author{
ATB Annual Technology Baseline \\ DOE U.S. Department of Energy \\ EERE Office of Energy Efficiency and Renewable Energy, DOE \\ EIA \\ U.S. Energy Information Administration \\ FCEV fuel cell electric vehicle \\ GREET Greenhouse Gases, Regulated Emissions, and Energy Use in Transportation \\ $\mathrm{H} 2 \mathrm{~A}$ \\ Hydrogen Analyses \\ HDSAM Hydrogen Delivery Scenario Analysis Model \\ LCOD levelized cost of driving \\ VMT vehicle miles traveled \\ WTT well to tank \\ WTW well to wheels
}

